\title{
The Economy of Ransoming in the Early Modern Mediterranean
}

University Press Scholarship Online

\section{Oxford Scholarship Online}

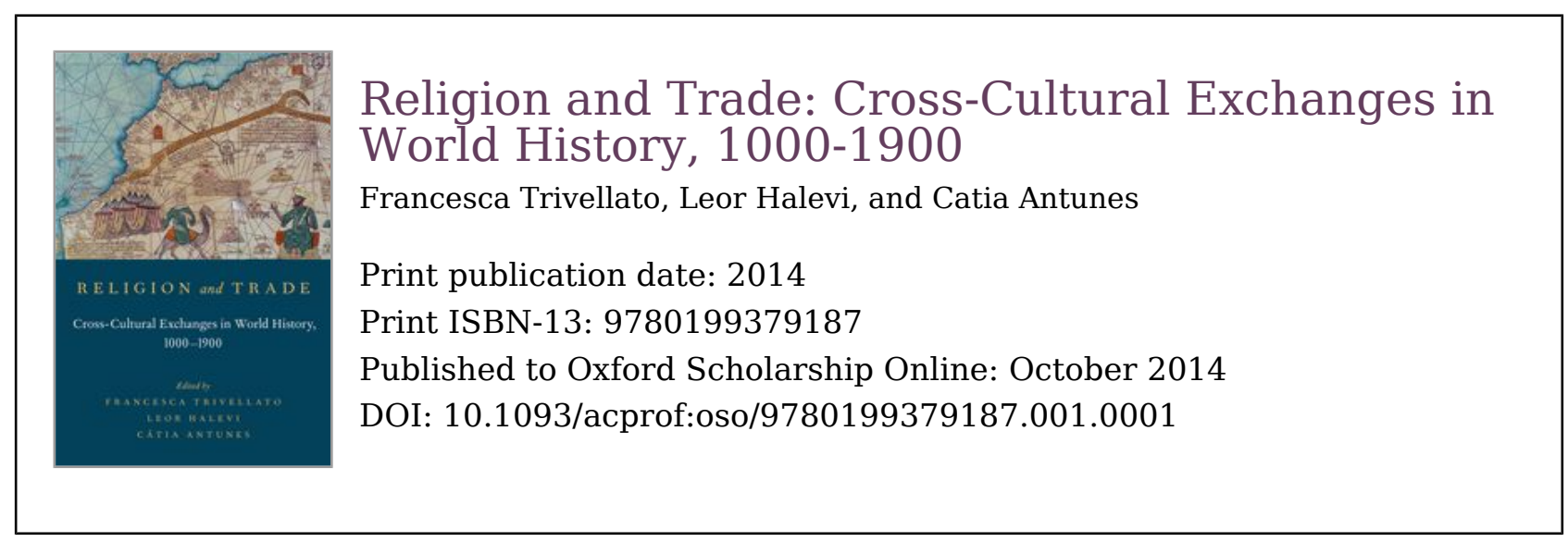

\section{The Economy of Ransoming in the Early Modern Mediterranean}

A form of Cross-Cultural Trade Between Southern Europe and the Maghreb (Sixteenth to Eighteenth Centuries)

Wolfgang Kaiser

Guillaume Calafat

DOI:10.1093/acprof:oso/9780199379187.003.0004

\begin{abstract}
Keywords
Drawing from diplomatic sources, commercial treatises, and legal documents, this chapter describes the ransoming of captives as an important economic sector of the early modern Mediterranean. It argues that, far from being an economy of booty and plunder that obstructed commercial exchanges, corsairing in the Mediterranean sustained a constant trade in captives that crossed religious, legal, and political boundaries. The official function of corsairing was to damage the enemy's economic activities. But in practice, corsairing also contributed to intensify contacts between Christian, Muslim, and Jewish merchants in the western Mediterranean.
\end{abstract}




\section{The Economy of Ransoming in the Early Modern Mediterranean}

Keywords: corsairing, captivity, ransoming, Christians, Muslims, Jews, western Mediterranean, early modern

THE RANSOMING OF captives was an important economic sector of the early modern Mediterranean, not only because the total amount of ransoms was very high, but above all because trading captives allowed merchants and ship captains to establish commerce with political and religious enemies. ${ }^{1}$ Captives' trade and ransoming were not an exclusively early modern phenomenon. Prisoners or captives had been enslaved or ransomed since ancient and medieval times. ${ }^{2}$ Nor was ransoming specific to the Mediterranean. We find similar practices in early modern times in the Hungarian borderlands dividing (p.109) the Habsburg and the Ottoman Empires, as well as in the Great Lakes region of North America, which Richard White famously called the "middle ground."3 Furthermore, to ransom a captive did not necessarily mean to free him or her. Roman law stated that ransomed persons returned to the status they held before their captivity (postliminium), although it remained uncertain whether the ransomed belonged to the ransomer until full reimbursement (retentio). ${ }^{4}$ In sixteenth-century Brazil, the Portuguese bought prisoners from Indian tribes, such as the Tupinambi, in order to make them into their own slaves - a practice known as rescate, which could mean both ransoming and rescue. ${ }^{5}$ This connection between war and enslavement is still present in John Locke's definition of slavery as "a State of War continued, between a lawful Conquerour, and a Captive." 6

Warfare was also an economic affair with promising gains. These included plundered goods (among which was live booty), ransoms of prisoners, and "ransoms of the country" (the appatis paid by peasants or the sauvegardes negotiated by villages and towns for immunity or to avoid occupation and plundering). ${ }^{7}$ The economics of warfare followed specific codes: high ransom signified the recognition of high status, a ranking visible, for example, in the difference between the ransom for an officer and a simple soldier as they appeared on official price lists. Warfare was also accompanied by non-economic rituals. In addition to gracious liberation, the exchange of prisoners by "quarter" or Kartell after a battle 


\section{The Economy of Ransoming in the Early Modern Mediterranean}

was a question of honor and a sign of mutual respect. ${ }^{8} \mathrm{~A}$ whole literature has described the process of increasing state (p.110) control and "civilizing" warfare between European powers, and recent research, mainly concerned with intraEuropean wars, has shed new light on the reality of warfare, stressing the fact that violence in the early modern period was not random, brutal, and irrational, but followed highly ritualized practices in wartime. ${ }^{9}$ Captivity and ransoming were part of these written and often unwritten rituals.

In the Mediterranean, corsairing shaped the commercial and diplomatic relations between southern Europe (Iberia, the French kingdom, and the Italian regional states) and North Africa. Fernand Braudel called this endemic activity the "secondary form of war" and placed its flourishing in the period between the battle of Lepanto (1571) and the end of the seventeenth century, which he labeled the "century of corsairing." 10 Of course, this "little war" added to the difficulties inherent in cross-cultural commercial interactions between regions controlled by Muslim and Christian powers. We argue, though, that far from just constituting an obstacle for mercantile exchanges (a mere economy of booty and plunder), corsairing in the Mediterranean, with its concomitant trade in captives, furnished a trading framework that crossed religious, legal, and normative boundaries. This apparent paradox comes with a corollary argument: in order to reconstruct the history of the economic relations between Muslim and Christian regions in the early modern period, we need to take into consideration a broad array of primary sources, which illuminates the mercantile and maritime practices that structured commercial flows and which is not confined to diplomatic sources and commercial treatises. In this chapter, for example, we will make ample use of legal documents.

The Mediterranean, in short, stands out both as an area with distinctive common characteristics and as a region filled with political conflict and cultural diversity. It thus enriches our understanding of what historians and anthropologists have called, following Philip D. Curtin, "cross-cultural trade." By "cross-cultural trade," scholars mean a variety of phenomena. 


\section{The Economy of Ransoming in the Early Modern Mediterranean}

We will resort to this concept in very specific terms. To start, we posit that agents involved in cross-cultural trade shared neither the same mother tongue nor the same religion, and they lived in distinct political and normative contexts. Consequently, we define cross-cultural trade, at one and the same (p.111) time, as a cross-religious, cross-political, and cross-legal trade. Francesca Trivellato rightly warned historians not to use "cross-cultural trade" as a generic expression. "An instantaneous transaction between two strangers" is not, she reminds us, "an instance of crosscultural trade," in particular because "such exchanges [...] involve no credit and limited risks because traders usually can inspect the merchandise." 11 However, we can legitimately consider that a finite transaction bringing two strangers face to face as part of a more regular flow of exchanges (which is precisely the case of the commerce of captives) can entail risks, in particular abuses by agents in a position to exert violence, more or less legally. So we add two further criteria to the definition of cross-cultural trade. The first is the risk inherent in the nature of the transaction, in a context of hostility or latent violence; the second is the frequency and the regularity of this type of transaction.

Cross-cultural trade is not the equivalent-although this is often how it is portrayed-of long-distance trade. The geographical proximity of the Ottoman Empire and Morocco to many Christian states produced intense commercial exchange but did not lead in any automatic fashion to the creation of a common legal system; in fact, the difficulty of crossing existing cultural boundaries persisted over time. Furthermore, if corsairing and the commerce of captives were ancient activities, common to both the Christian and Islamic worlds, they did not necessarily give rise to uniform practices. For instance, the rules about captures at sea-crucial in the corsairing context-could vary considerably between the Maghreb and the European countries of jus commune. ${ }^{12} \mathrm{We}$ can thus approach the Mediterranean as a laboratory that allows us to analyze the historical processes that generated both dense commercial networks and a persisting cultural and legal separation between Islam and Christendom. In seeking to unravel this apparent paradox, we follow the noted

Page 4 of 36 


\section{The Economy of Ransoming in the Early Modern Mediterranean}

Norwegian anthropologist Fredrik Barth and approach these processes as the fruit of constant interactions between distinct groups and states. ${ }^{13}$

\section{A Lucrative Business}

Capturing and ransoming in the Mediterranean took place mainly (but not exclusively) in the context of the confrontation between Christian and Islamic powers, such as the Crusades, jihad, or the Reconquista. Violence was thus at the core of (p.112) captives' trade in the Mediterranean. Following Janice E. Thompson, corsairing was a form of extraterritorial violence practiced as part of a commercial politics of violence conducted by privateers, military orders, and North African "state corsairs" that were issued an official license by sovereign or another legitimate authorities. ${ }^{14}$ Stressing the difference between corsairing and piracy proves to be important: corsairs were official and legitimate warriors, who acted under the formal supervision of a state and according to the laws of war and peace; they carried on themselves either passports or commissions, and were supposed only to attack enemy ships in wartime, like the so-called "privateers" in the North European and Baltic seas, as well as in the Atlantic. By contrast, pirates were "the enemies of all nations" (hostes humani generis): they acted for themselves and did not obey any sovereign. ${ }^{15}$ In the Mediterranean context, the term "Barbary pirates," used in European discourse up to the twentieth century, casts doubt on the legitimacy of the Maghrebi authorities. Formally under Ottoman sovereignty, the rulers of Algeria and Tunisia were denounced by European diplomats as violent usurpers of power and, consequently, the corsairing activities that they sponsored were portrayed as mere piracy. ${ }^{16}$

On both sides of the Mediterranean, captives were made to serve on galleys, in mines and mills, in agriculture and domestic service; ${ }^{17}$ when they possessed specific skills, (p.113) they were employed in shipbuilding or customs offices; on rare occasions, they were even forced to work as translators, as in the case of al-Hasan al-Wazzan, alias Leo Africanus, who in the 1520s was put to work on the Arabic manuscripts of the Vatican library. ${ }^{18}$ 


\section{The Economy of Ransoming in the Early Modern Mediterranean}

Virtually all primary sources refer to captives indistinctively as "slaves." It is thus not surprising that captives also called themselves "slaves" in their letters and petitions. Captives were also considered as part of the traditional workforce of servile labor. Slaves were a presence in most Italian, Spanish, and Portuguese cities. If in the European literature Algiers and Tunis are often cited for their large slave population, we ought to remember that Lisbon, Seville, Genoa, Messina, and Livorno also had flourishing slave markets and numerous resident slaves during the early modern period. ${ }^{19}$ European consuls in overseas ports were important slave traders in the Mediterranean. Thus the correspondence of the French consul François Cotolendy in Livorno with the French secretary of state of the navy tells us about the competition between the French and the Spanish consuls for the purchase of Muslim slaves in the Tuscan port. Cotolendy complained to his superior about the order to buy slaves for no more than 110 piasters each, while in 1683 the minimum price on the market was 120 piasters. The Spanish consul spent as much as 150 piasters to buy a slave. ${ }^{20}$

Several European and non-European languages distinguished between a slave and a captive: esclave/captif in French; schiavo/cattivo in Italian; esclavo/cautivo in Spanish; escravo/ captivo in Portuguese; slaaf/gevangene in Dutch. A similar distinction was also made in early modern Algiers between i ilj (the European slave) and asîr (the captive). ${ }^{21}$ The difference did not refer to the type of servile status, but to the possible outcome of that status, that is, liberation through the payment of a ransom in the case of captives. ${ }^{22}$ The economic logic of owning slaves and captives also differed. Ransoming normally yielded a higher profit to the owner than the price (p.114) that sellers thought they could obtain on the slave market. Slaves had a price determined by their value of use, their productive and reproductive capacities, and their skills; by contrast, captives had a value of exchange, their ransom being based on an estimation of how much others-family or friends, religious charity organizations or political authorities-would be able or willing to pay for their freedom. ${ }^{23}$ Moreover, ransoming was open-ended; its final amount did not always correspond to the initial proposal, which frequently began as a "test" ${ }^{24}$ based on

\footnotetext{
Page 6 of 36
}

PRINTED FROM OXFORD SCHOLARSHIP ONLINE (www.oxfordscholarship.com). (c) Copyright Oxford University Press, 2015. All Rights Reserved. Under the terms of the licence agreement, an individual user may print out a PDF of a single chapter of a monograph in OSO for personal use (for details see http://www.oxfordscholarship.com/page/privacy-policy). Subscriber: Ecole 


\section{The Economy of Ransoming in the Early Modern Mediterranean}

the parties' expectations in a process of negotiations in which the object (the live booty) could take part, and often did so in a consequential manner. The historical and analytical difference between captives and slaves should be stressed to avoid an improper analogy between the European Atlantic slave trade and Mediterranean "white slavery," or "white captivity." 25 To insist on this distinction is not to use an excessively (politically) correct language; it is to take stock of a distinction that contemporaries made.

Not every captive was worth the same amount, and not every captive was used for the same goal. The instructions given by the grand-master of Malta to the Knights of Saint John departing on a corsairing venture (the corso) in 1608 distinguish carefully between various groups among the live booty. They specify that women and children should be sold at the best price on the slave market (for instance, in Messina); that rich captives able to raise large funds may be liberated immediately against payment of ransom; and that only strong men, who could serve in the galleys, should be brought to Malta. ${ }^{26}$ Similarly, in Tunis, Algiers, and the Hungarian borderlands, the Ottomans classified captives into groups according to rank and wealth. Spanish sources call cautivos de rescate (captives to be ransomed) those for whom Muslim masters in Algiers expected to obtain a substantial ransom; ${ }^{27}$ these men were held separately from other captives who were designated as workers. Along the Hungarian (p.115) frontier, captives considered too poor to be ransomed were immediately sent to the slave markets in the Ottoman Empire. ${ }^{28}$

The distinction between captives and slaves was made here along social lines. Slavery was a possible destiny for the poor and the humble, and a decisive step downward on the ladder of dependent and servile labor. Family solidarity, religious charity, and political reasoning sometimes cut across social hierarchy and came to the aid of the most humble. ${ }^{29}$ But in those instances, liberation could mean imprisonment for debt until the entire contracted loan was repaid. ${ }^{30}$ Maddalena Bindi was a widow ransomed with her two children at Tunis through the charity of the Roman Arciconfraternita del Gonfalone in 


\section{The Economy of Ransoming in the Early Modern Mediterranean}

1789. A year later she petitioned the officers of the confraternity, asking for financial support because she could not earn a living after her liberation and return to Rome. ${ }^{31}$

Ransoming followed a variety of customary and institutionalized practices ranging from the enforcement of individual written contracts (certainly the principal form), ransoming on the spot on the shore (at the spiaggia or playa) after a raid (a practice called alafía in Andalusia), ${ }^{32}$ and up to the mediation of religious orders, confraternities, charity organizations, royal or municipal institutions, and diplomatic and military missions. ${ }^{33}$ It is primarily through the documentation produced by formal institutions that we learn about the realities of ransoming and acquire (p.116) fragments of narratives that reveal the frictions and the underlying values and cultural codes that sustained this kind of cross-cultural negotiations.

A multiplicity of forms of exchange, each following a different and sometimes contrasting logic, coexisted in Mediterranean ransoming. The full costs of redemption, that is, the composition of the "price of liberation," also inform us about the many actors involved in these transactions. To the ransom paid to the master (the first payment), we have to add different taxes, customs, and transit fees due to local authorities, the cost of documents (especially passports and safe-conducts), consular fees (the chancellery of European consulates functioning as notary), transport costs, middlemen commissions, and, last but not least, a variety of financial services such as credit, insurance, and cambio marittimo (an elementary form of a bill of exchange that included the transport and exchange of currency). A surviving account book of a voyage to Algiers kept by merchants from Marseilles in 1651 shows a series of entries concerning individually named slaves to be redeemed, but also more general entries "for the slaves." This wording suggests that there were both clear commissions for specific persons and little sums invested for the general purpose of ransoming. ${ }^{34}$ The price of liberation thus normally increased the sale price of the captive by about one-third-and in some cases by much more. ${ }^{35}$ 


\section{The Economy of Ransoming in the Early Modern Mediterranean}

In 1757, the acting French consul in Algiers wanted to ransom two men from Rome who had served on a Neapolitan galley. The dey (the main ruler of the Algerian Regency) refused categorically the Frenchman's offer, arguing that the two Romans had been on a galley and that, consequently, he wanted to make a prisoner exchange. ${ }^{36}$ The exchange of prisoners serving on the galleys of the enemy, part of the peace treaties between France and the Barbary powers, was a constant subject of friction and complaint, especially from the Maghreb authorities who claimed that Europeans regularly reneged on their commitments. Prisoners were often not brought back but were sold on enemy galleys; moreover, a prisoner's health or rank was sometimes disputed. ${ }^{37}$ What was at stake in all cases of prisoners' exchange was not only money or tribute, but also reciprocity and respect, according to a supposed code of warfare that was shared across the religious divide, even in time of open hostilities. ${ }^{38}$

(p.117) Quite often, as in the 1580s, the Spanish, Portuguese, and Neapolitan missions of religious orders and confraternities that came to Algiers in order to ransom captives were required to pay taxes on the money they brought with them. The so-called "Redemptions" of Portugal and Spain, that is, religious orders specialized in the redeeming of captives, paid 11.5 percent upon entrance and 3 to 4 scudi per redeemed slave upon exit; the Redemption of Naples only paid 6.5 percent at the entrance and nothing on departure. ${ }^{39}$ Political pressure could reduce dramatically the funding available to redemptions. In 1748 the agent and middleman of the Roman Arciconfraternita del Gonfalone in Tripoli (Libya) told the superiors of the confraternity that he had been forced by the bey (provincial governor) of Bengazi to sell a charge of grain for a very low price; he was thus asking the superiors to send him new funds via Malta or Livorno. ${ }^{40}$

The cliché of the cruel Barbary corsairs that dominated the European discourse of the time included a notion of the corsairs' greed. In reality, the mere lure of profit- "l'interesse del denaro," in the words of the Roman redeemers in Algiers in the 1580s-was not the only element that determined a captive's price. ${ }^{41}$ The redeemers had to deal with Arnaut 


\section{The Economy of Ransoming in the Early Modern Mediterranean}

Mami (Māmī Arnawūt), the Albanese corsair who converted to Islam and the famous ra'is who captured Cervantes. ${ }^{42}$ Mami sold a number of his slaves at scandalously high prices, according to the Roman board of governors (cancellieri). ${ }^{43}$ But Roman redeemers did not know much about the local habits and customs, or how to negotiate with the great and powerful in Algiers. ${ }^{44}$ The high prices they eventually paid had to be considered as a recognition of Mami's high status and accepted as an offer and a grace. In return, the famous $r a^{\prime}$ is agreed to liberate the captives without prior payment, on the word of honor of the redeemers. For the Spanish legal scholar Bartolomé Clavero, these exchanges would represent transactions occurring in the world of antidora, an economic and symbolic system dominated by honor, gift, and grace, in which the buyer may accept a high price (though not necessarily pay it) in recognition of the seller's social position. ${ }^{45}$

Practices inspired by warfare customs compensated for the frequent lack of trust among masters, captives, and redeemers, and the fear of arbitrary decisions and (p.118) disruptive incidents. The political and diplomatic relations between European and Maghrebi authorities made frequent use of hostages. Hostages were exchanged to enforce the truce between Spain or its presidios and local authorities in the Maghreb, between Marseilles and Tunis in 1616, and as part of the peace treaties between France and Tunis in 1605 and between France and Algiers in $1619 .{ }^{46}$ A hostage (the captive or sometimes the buyer himself) was a living bond who facilitated transactions in a context of open hostilities; sometimes that person could function as collateral and facilitate further business. ${ }^{47}$ Anticipations or gestures of goodwill, such as the liberation of a slave, serving as a messenger or as the first move in negotiations for an exchange of captives, were also helpful. In 1598, for example, in a famous incident, Sinan Pacha Cigala, a commander of the Ottoman fleet, contacted the viceroy of Sicily and asked him to visit his old and ill mother who lived on the island. Sinan Pacha's letter was transmitted through a Christian slave liberated for the occasion. ${ }^{48}$ These gestures of politeness or magnanimity increased one's own credibility and showed that

Page 10 of 36

PRINTED FROM OXFORD SCHOLARSHIP ONLINE (www.oxfordscholarship.com). (c) Copyright Oxford University Press, 2015. All Rights Reserved. Under the terms of the licence agreement, an individual user may print out a PDF of a single chapter of a monograph in OSO for personal use (for details see http://www.oxfordscholarship.com/page/privacy-policy). Subscriber: Ecole Normale Superieure; date: 28 October 2016 


\section{The Economy of Ransoming in the Early Modern Mediterranean}

one took the risk of being deceived. ${ }^{49}$ "Credibility without trust" was generated through a multitude of business, military, and ritualistic relations in which the same actors were involved and in which everyone could find him- or herself in a hostage situation: in a nutshell, the threat of being taken captive helped to keep actors from reneging on their promises. ${ }^{50}$

\section{Middlemen}

The redeemers of the Roman Gonfalone confraternity or other Redemptions-and indeed all Christian institutions involved in redeeming captives-relied on merchants who were or had correspondents in North Africa. In the early modern period, (p.119) there were still also fakkak-in or alfaqueques, merchants specialized in ransoming, who made a living by negotiating the liberation of Muslim slaves in Livorno or Christians in the port cities of North Africa.

This remained a risky business, but its adventurous aspects were fading away. In Spain, the redeeming of Christian slaves was an obligation fixed by the Crown for merchants trading with the Barbary Coast, the moral compensation and legitimation for trading with the so-called "infidels." In practice, this obligation allowed merchants to combine ransoming with commodity trade, including the illegal export of smuggled goods (weapons, material for shipbuilding like iron, tin, wood, or rigging). Royal licenses were sold regularly; they permitted merchants to trade in goods and slaves in North Africa upon payment of an additional indirect tax of 10 percent. ${ }^{51}$ In the sixteenth century English merchants resident in Cadiz also acted as alfaqueques, organizing the transfer of money through their network of partners and agents in London and Livorno. ${ }^{52}$ In Algiers and Tunis, in addition to the many Jewish merchants active between Livorno and North Africa, a multitude of modest merchants revolved around the French consulate and its chancellery. They came from Sicily, Corsica, Malta, or Marseilles and offered-in competition with one another-their services to newcomers, merchants, and redeemers. ${ }^{53}$ Their services were twofold: first, they brought local knowledge because they knew with whom and how to 


\section{The Economy of Ransoming in the Early Modern Mediterranean}

negotiate; second, they helped European merchants and merchant-bankers to establish relations with individuals who specialized in currency trade. Middlemen and correspondents were crucial in the ransoming business. Having no correspondent in Tripoli (Libya), the Roman redeemers based in Algiers in the 1580s were unable to locate an Italian captive and to enter into negotiation with his master. ${ }^{54}$

Networks of correspondents became particularly necessary in wartime, when regular means of communication were interrupted, as the Gonfalone's correspondent in Tripoli in 1748 discovered when he desperately asked to receive money via Venice, Livorno, Malta or Tunis. ${ }^{55}$ Mediation had its price: the standard commission rate amounted to 4 percent. When wartime led to the complete suspension of trade, the correspondent in Tripoli asked for 12 percent per transaction. ${ }^{56}$ Competition (p.120) between ransoming partners could also increase the prices: for example, in the 1580s, the Capuchin friars of the Gonfalone in Algiers were worried about the arrival of wealthy Spanish and Portuguese redeemers, who aroused keen interest among local slave masters and inflated the ransoms. ${ }^{57}$

The redeeming of captives was a costly operation that raised the problem of financial transfers between Europe and the Maghreb. Would it be better to transport Spanish gold or silver coins to Algiers and Tunis (for which a royal permission to export money was needed), or should one prefer to borrow money locally from European merchants or via letters of exchange? The first option seemed to some more attractive: in the 1580s, to bring money from Marseilles to Algiers waswithout the transport and other transaction costs, such as insurance fees-18 percent cheaper than using letters of exchange. ${ }^{58}$ Missions organized by religious orders or charity organizations in the sixteenth century utilized a myriad of little ships and their captains, otherwise active in coastal shipping or coral fishing, in order to ship bullion and coins across the Mediterranean. ${ }^{59}$ However, as the case of the ships and captains of the French Compagnie du Corail (founded in Marseilles in 1553) testifies, the transport of cash was a risky and costly business. Insurance costs were about 6 percent, and the captain of the transporting ship received a 2 percent

Page 12 of 36

PRINTED FROM OXFORD SCHOLARSHIP ONLINE (www.oxfordscholarship.com). (c) Copyright Oxford University Press, 2015. All Rights Reserved. Under the terms of the licence agreement, an individual user may print out a PDF of a single chapter of a monograph in OSO for personal use (for details see http://www.oxfordscholarship.com/page/privacy-policy). Subscriber: Ecole Normale Superieure; date: 28 October 2016 


\section{The Economy of Ransoming in the Early Modern Mediterranean}

commission. Once the captain arrived in Algiers with the cash, he incurred additional costs, including the percentage directly taken by the $d e y$, which generally amounted to 11.5 percent in the case of the French or the Roman missions in the 1580s. Thus transport and insurance costs as well as taxation at the entry into the port eliminated the estimated advantage (18 percent) of transporting bullion or coins. Ludovico Felix, a merchant from Marseilles, made this calculation in 1584-1585 when trying to convince the Roman redeemers of the Gonfalone, who wanted to travel to Algiers via Genoa and Marseilles, to buy bills of exchange worth 3,000 scudi d'oro in Marseilles and redeem them in Algiers, rather than carry the money on board the ship. ${ }^{60}$ But the benefits of the deal proved to be illusory: bills of exchange drawn by the merchantbankers Bandinis of Rome, the Strozzis of Lyon, and Felix in Marseilles, as well as the financial services offered by "their merchant" (Felix's correspondent) in Algiers, Guillaume Borgal, (p.121) ruined the Roman redeemers completely. ${ }^{61}$ Up to 69 percent of the money engaged in the Gonfalone's mission never left Europe and was absorbed by the middlemen specialized in the transfer of money. ${ }^{62}$ In other words, the intra-European money market itself could involve as many risks as cross-cultural exchanges and, in any case, had a considerable impact on the working of Mediterranean ransoming.

Jewish merchants from Livorno, Algiers, and Tunis played a central and contested role in this trade. Accusing Jewish traders of charging exorbitant interest rates on the cambio marittimo (up to 15 percent of the first payment plus fixed fees) and of speculating on the exchange rates between local currencies and the Spanish pieces of eight (the silver coin of international trade, sometimes also called piasters or dollars), Catholic institutions like the Genoese Magistrato per il riscatto tried to avoid or at least to limit the mediation of Jewish agents and made recourse to a variety of other merchants involved in the ransoming business. ${ }^{63}$ Compared to the abovementioned credit instruments, the albarano, a type of promissory note used by the Neapolitan Santa Casa della Redenzione and Pio Monte della Misericordia, was

Page 13 of 36 


\section{The Economy of Ransoming in the Early Modern Mediterranean}

rudimentary but very useful: a simple sheet of paper, printed by the eighteenth century, certified that the religious institutions would pay a certain amount once the captive mentioned on the document had returned. ${ }^{64}$ The albarano could thus be used by a merchant or another person who had given credit to the captive, to be reimbursed in Naples. ${ }^{65}$ The lure of profit attracted not only large merchants and institutions but also minor actors and investors to the captives' trade, in spite of its high risks. Private merchants from Sicily active in the trade with the Maghreb offered credit at 5 percent interest per month or claimed 33 percent of the captives' price (but were fined in case of unsuccessful negotiations). ${ }^{66}$

\section{Securing Cross-Cultural Trade: Shared Knowledge and Simultaneous Transactions}

How to secure these commercial transactions involving masters and slaves, captives and multiple creditors, often bound by a series of contracts in a cascade of (p.122) microcredit? Legal certification and enforcement played a role. Credit contracts were sealed before the chancellery of the French consul in Tunis or Algiers, as well as before a notary in Italy or Provence. Contracts could thus be concluded according to the legal regime of the place of departure and, if necessary, they were doubled by another contract drafted or registered on the opposite shore of the Mediterranean. Their form, clauses, and guarantees shared a lot of similarities with the Islamic contract between masters and slaves used for eventual emancipation, the mukätaba. ${ }^{67}$

There was a considerable amount of shared knowledge about the organization of the redeeming of captives among Muslims, Jews, and Christians. A religious foundation in Ottoman Algiers, the Waqf al-Haramayn, had some assets endowed for the redemption of Muslim captives. ${ }^{68}$ The redemption was organized mainly by the political authorities, but the assets endowed, for example, by janissaries, who had left the barracks for the purpose of redeeming their former companions, were not: the result was "an institution which functioned by managing assets, like a social fund at the 


\section{The Economy of Ransoming in the Early Modern Mediterranean}

service or a specific body of people." ${ }^{69}$ In medieval Spain, the communities of Mudejars (Muslims living under Christian rule) had their networks for redemption of Muslim slaves based perhaps on models and formulas of Jewish communities in the medieval eastern Mediterranean. ${ }^{70}$ The Cassa per il riscatto degli schiavi of the Livorno Jewish community (to which all members were obliged to contribute), and its equivalent in Venice and Amsterdam, may have inspired the Sklavenkasse of Hamburg (founded in 1624). ${ }^{71}$ Ironically, when the grand duke of Tuscany reformed the Livorno's Christian fund to redeem slaves and captives in 1748, he introduced the obligation to contribute to that fund, perhaps borrowing from its Jewish counterpart in Livorno. ${ }^{72}$

(p.123) The practice of money lending in Tunis through the (oral or written) qirad also seems to have been quite similar to the habit of collecting a myriad of little sums used by modest coastal captains in Marseilles and in the secondary ports of Provence in order to finance their convoys (the so-called caravanes). Moreover, different forms of commercial associations allowed by Islamic law-mudharaba or sharikahad parallels in Europe. ${ }^{73}$ With respect to maritime law, there may have been borrowings between the Byzantine Empire, the Islamic world, and the European countries of ius commune. ${ }^{74}$ Medieval collections of maritime customs and laws, such as the Catalan Consolat de Mar, could be easily adapted to the Maliki jurisdictions current in the Maghreb Regencies. ${ }^{75}$

Cross-cultural exchanges, in sum, did not necessarily need the creation of a common or a hybrid legal framework. The existence of analogous if distinct commercial customs and contracts facilitated dealings made with minimal knowledge of other normative frameworks. We find concrete examples in commercial litigation: the merchants' court of Marseilles (tribunal de commerce), for instance, accepted statements made before the local judge of Tunis (the qadi) as evidence and legal proof. ${ }^{76}$ European consulates in the North African Regencies served in this respect as an interface. Following the European capitulations with the Ottoman Empire, consuls normally acted as judges in the first instance in commercial and civil disputes between their fellow countrymen and other

Page 15 of 36

PRINTED FROM OXFORD SCHOLARSHIP ONLINE (www.oxfordscholarship.com). (c) Copyright Oxford University Press, 2015. All Rights Reserved. Under the terms of the licence agreement, an individual user may print out a PDF of a single chapter of a monograph in OSO for personal use (for details see http://www.oxfordscholarship.com/page/privacy-policy). Subscriber: Ecole Normale Superieure; date: 28 October 2016 


\section{The Economy of Ransoming in the Early Modern Mediterranean}

protected subjects. Their legal services helped merchants find amicable solutions, and their sentences had the value of legal arbitration. For example, Claude Sévert, the French deputy consul in Tunis during the first decades of the seventeenth century, judged cases between Christian merchants and, because he charged less than the qadi, he was also sought after in civil and commercial disputes between Christians and Muslims. ${ }^{77}$ In cases in which civil suits crossed religious boundaries, North African authorities tolerated the recourse to an "infidel," so long as the latter did not encroach on the qadi's prerogatives and the parties agreed to his arbitration. Consuls were consequently allowed to resolve commercial and maritime disputes, especially in port cities frequented by migrants, sailors, and traders. However, according to Daniel Goffman, European merchants in (p.124) the Ottoman Empire sometimes preferred being judged by the qadi if they perceived their own consul to be too partial. ${ }^{78}$

Consuls did not necessarily belong to the city or country they represented. In the 1620s and 1630s, the "consul of the Armenian nation" in Livorno was the Hungarian-born Andrea Signorini. He spoke Italian, Hungarian, Ottoman Turkish, and, in all likelihood, Armenian. He was therefore able not only to translate petitions, claims, and cross-examinations of Armenian merchants who settled in the Tuscan port during those years, but also to issue legal certificates, like a notary. ${ }^{79}$ In the North African Regencies, the redeeming of Christian captives was one of the main tasks of European consuls. The importance of the ransoming business explains why the Venetian consul in Algiers was appointed by the Provveditori sopra Ospedali e Luoghi Pii (Inspectors of Hospitals and Pious Places) and not, as the other consuls of the Republic, by the Cinque Savii alla Mercanzia (the Board of Trade). His principal role clearly was to redeem slaves and captives whom Algerian privateers had taken. ${ }^{80}$ The case of Moshe Israel, a Jewish merchant settled in Algiers in the 1590s, is a good example. He was appointed consul by the Republic of Venice in 1622 because he had long been involved in the redemption of captives in various Maghreb ports. He had a good reputation with Venetian and Christian merchants, and also with Algerian privateers. By appointing Israel consul, the Venetian

Page 16 of 36

PRINTED FROM OXFORD SCHOLARSHIP ONLINE (www.oxfordscholarship.com). (c) Copyright Oxford University Press, 2015. All Rights Reserved. Under the terms of the licence agreement, an individual user may print out a PDF of a single chapter of a monograph in OSO for personal use (for details see http://www.oxfordscholarship.com/page/privacy-policy). Subscriber: Ecole Normale Superieure; date: 28 October 2016 


\section{The Economy of Ransoming in the Early Modern Mediterranean}

Provveditori built on the preexisting expertise of a Jewish broker. We may note here that consuls of the maritime Republic of Ragusa (Dubrovnik) in Algiers and in Albania at the end of the sixteenth century were often Jewish. ${ }^{81}$ Consuls and commercial courts also played an important role in the circulation of information about different legal customs, which they translated into local contexts and for local institutions.

The circulation of information about laws and jurisdictions between Europe and North Africa was intense. In the 1620s, Murād Bey, a Corsican convert to Islam and the only "Renegade" to become bey of Tunis, made recourse to the sovereign court in Livorno that had civil and commercial jurisdiction at first instance. The litigation was about money and inheritance. One of his Mamluks (a former slave converted to Islam) had died; alive, he had lent money to a Corsican merchant in Livorno, and (p.125) the master now claimed the money of his dead slave. The tribunal of the governor in Livorno asked for statements on the following questions: Do masters inherit money lent by dead slaves in the Abode of Islam (dar-al-islam)? If yes, can masters claim the money when the debtor lives in Christian countries? The court interrogated merchants and sailors familiar with the business customs of Tunis. It also received a document known as "acknowledgment of debt" sent by Claude Sévert, the French consul in Tunis. Sévert added that it was common practice in Tunis-and indeed in the whole Ottoman Empire-that "masters inherited claims from slaves in the land of Islam." 82

\section{A Lubricant of Trade}

Trading captives was a lucrative activity in the early modern Mediterranean and involved, as we have just seen, several brokers and commercial agents. In addition to understanding the mechanisms that governed the economy of ransoming, it is important to assess the importance of trading captives within the overall exchange patterns between Mediterranean Europe and North Africa. Although peace and commercial treatises allowed European and, to a certain extent, Maghrebi ships to call at the ports of the other shore of the Mediterranean, there were a lot of interdictions and normative restrictions that hindered the business with the "infidel." For instance, the 


\section{The Economy of Ransoming in the Early Modern Mediterranean}

papal bulls In Coena Domini (1496) forbade Christians from trading in those products that could potentially reinforce the Muslim military power. ${ }^{83}$ In 1563 , Pius IV set out a number of restrictions, continuously repeated during the seventeenth and the eighteenth centuries, prohibiting in particular the commerce of horses, weapons, wire, tin, and steel. ${ }^{84}$ The Iberian crowns and the Italian city and regional states recognized the validity of the bull, but the French monarchy never accepted it, nor did the Protestant powers, for obvious reasons. ${ }^{85}$ In North Africa, some injunctions against trading in the land of the Christians were pronounced by Maliki jurists. For example, in a treaty of the fourteenth century with the king of Majorca, a Muslim ruler forbade Christian traders from buying weapons, leather, (p.126) bread, and other strategic goods. ${ }^{86}$ But here we must be careful. ${ }^{87}$ If we over-interpret the impact of those injunctions to explain the modest presence of Muslims from North Africa in Christian Europe, we risk minimizing the hostility toward Muslim merchants and sailors in Christian port cities, a latent hostility that persisted even if it rarely turned into open violence, as during the so-called "massacre of the Turks" in Marseilles in $1620 .{ }^{88}$ A great number of legal and religious safeguards existed for limiting commercial exchanges and contacts between the Maghreb and Europe. Those restrictions added to the fear of abuses in the port cities of the "infidels." As a result, merchants and sailors had to develop different strategies to circumvent the many obstacles facing the commerce between Islam and Christendom in the Mediterranean.

Trading captives offered an expedient that not only justified trafficking with the "infidels" more generally, but also provided merchants and ship captains with safeguards against potential abuses. The Spanish historian Rafael Benitez, analyzing the ransoming of captives between Valencia and Algiers in the early modern period, maintains that this activity functioned as a "lubricant" of trade and thus requires that historians pay greater attention to the central role that the trade in captives played for all economic exchanges between Europe and the Maghreb. ${ }^{89}$ Two cases brought before Tuscan commercial tribunals in the 1620s-the courts of the governor of Livorno and of the consuls of the Sea of Pisa-confirm the

Page 18 of 36

PRINTED FROM OXFORD SCHOLARSHIP ONLINE (www.oxfordscholarship.com). (c) Copyright Oxford University Press, 2015. All Rights Reserved. Under the terms of the licence agreement, an individual user may print out a PDF of a single chapter of a monograph in OSO for personal use (for details see http://www.oxfordscholarship.com/page/privacy-policy). Subscriber: Ecole Normale Superieure; date: 28 October 2016 


\section{The Economy of Ransoming in the Early Modern Mediterranean}

importance of carrying captives as part of the cargo when searching for new commercial opportunities in the Maghreb. The first case pitched a French shipowner settled in Livorno, Origène Marchant, against several merchants who chartered Marchant's ship or insured its freight. This trial took place because a "Flemish" (i.e., Dutch) ship captain, Theodor Cornelissen, committed what is known in maritime law as a "barratry," that is, an act of gross misconduct tantamount legally to a crime. Cornelissen and his crew were supposed to go from Livorno to Algiers with merchandise and cash amounting in total to 40,000 pieces of eight-a huge sum. But they dropped their few passengers in southern Corsica and fled with the boat and cargo. Merchants and insurers filed a suit against the shipowner, whom they considered an accomplice, or at least (p.127) partly responsible for Cornelissen's barratry, because Marchant had chosen him to complete the voyage to Algiers. According to the merchants of Livorno, Cornelissen should have aroused Marchant's suspicion in the first place because he was a former privateer with a bad reputation. ${ }^{90}$ Moreover, merchants and insurers thought it was suspicious that Cornelissen refused to take ransomed captives aboard. They explained very clearly that, in general, "it is something very wanted by captains of ships leaving from Livorno and going to Barbary to take on board ransomed slaves, and [ship captains] are very kind with them when they go aboard, because they can help both during the voyage in case of encounter with corsairs and once arrived in Barbary." 91 This statement is telling evidence of the advantage that a captain had in taking on board ransomed captives who would be welcomed in the port cities of North Africa. Furthermore, ransomed captives could certify, in case of an encounter with Algerian or Tunisian corsairs at sea, that the ship's captain was not a pirate, did not have hostile intentions against North African ships, and had the authorization to trade with the Maghreb. This very important point is evoked twice in the proceedings. ${ }^{92}$

Another case reveals the numerous difficulties in crossing boundaries and trading with the Maghreb in the early modern period. The galleys of the Knights of Saint John inspected and arrested the ship Il Sole off Malta. The Knights informed the

Page 19 of 36

PRINTED FROM OXFORD SCHOLARSHIP ONLINE (www.oxfordscholarship.com). (c) Copyright Oxford University Press, 2015. All Rights Reserved. Under the terms of the licence agreement, an individual user may print out a PDF of a single chapter of a monograph in OSO for personal use (for details see http://www.oxfordscholarship.com/page/privacy-policy). Subscriber: Ecole Normale Superieure; date: 28 October 2016 


\section{The Economy of Ransoming in the Early Modern Mediterranean}

Tuscan authorities about the inspection and about the fact that Il Sole transported smuggled goods. A Jewish merchant from Livorno, Judah Crespino, had two kegs of tin on board, while Joseph Franco, a Levantine Jew who had also settled in Livorno, was sending little knives and needles for making sails to a relative in Algiers. ${ }^{93}$ The Knights of Malta consequently decided not to return the whole cargo, in accordance with the papal bull In Coena Domini. ${ }^{94}$ The shipowner, now allied with the other merchants and insurers, accused the Jewish merchants of smuggling, referring as well to the papal bull (that being somewhat absurd since Crespino and Franco could not possibly be threatened with the excommunication sanctioned by In Coena Domini). In fact, the papal bull served, in all likelihood, to legitimate the depredation of the (p.128) Maltese corsairs. Eventually, the grand duke of Tuscany was asked to negotiate with the Maltese authorities to restore the goods to the merchants of Livorno. ${ }^{95}$

We can draw several lessons from this trial. Cross-cultural trade between Christian Europe and the Maghreb did not presuppose the existence of an informal "middle ground" that would offer the possibility to act outside formal regulations. On the contrary, trading with the Maghreb necessitated a continual transfer and intermeshing of documents, rights, exemptions, and practices that required the organization of a fitting procedure to make cross-cultural exchange possible. To reduce the uncertainty that was intrinsic to cross-cultural trade, merchants needed to obtain a license in the port of departure, to be well connected with North African traders (as was the case of the Jews in Livorno), and to transport ransomed captives and cash to remunerate local middlemen. ${ }^{96}$ Merchants could also smuggle certain goods as a way of enhancing the trade of licit commodities such as grain, leather, gum, and sugar. But the lawful nature of exchanges depended, as we have demonstrated, on the political and economic choices of the different European states that, with greater or lesser reluctance, granted trading licenses for the traffic with North Africa.

If the transportation of captives proved central to the organization of commercial exchanges between Muslim and

Page 20 of 36 


\section{The Economy of Ransoming in the Early Modern Mediterranean}

Christian regions, it was in part because ransoming was evidence of a successful negotiation. Thus respect for the procedures of ransoming turned out to be essential for maintaining good trading relations with North African or European partners. Another case brought before the civil and commercial court of the governor of Livorno in April 1624 illustrates this point. A Corsican ship captain, Bartolomeo Ambrogini, sued Pietro Corcia (Pedro Garcia?), a Portuguese surgeon and former captive in Algiers. ${ }^{97}$ Ambrogini's ship left Algiers in January 1624, but its captain did not know that it was carrying Corcia, who had been stowed away in the boat's hold by friends, inside a big trunk supposed to contain grain and other foodstuffs. Corcia's subsequent escape, without the ship captain's knowledge, posed problems to Ambrogini, who explained to the judges that if he tried to go back to Algiers, Corcia's former master would likely oblige him to pay the total amount of the ransom. If he decided not to go back, however, he would lose the goods he had let in Algiers and his good commercial relations in the city. Against Corcia, he claimed 1,000 piasters in compensation in order to pay the ransom of the surgeon and the extras that were generally asked in such cases. The precarious (p.129) commercial equilibrium built by Ambrogini to avoid snubs in Algiers had been jeopardized. While the transportation of ransomed captives made the exchanges with the Maghreb easier, the transportation of escaped captives was a considerable risk for the ship captain or the shipowner. Further, Ambrogini explained, he might not only lose commercial partners, but also risk being killed. In the written questions he put to Corcia and his friends who had helped him to escape, the ship captain explained that "in Algiers, to help slaves escape is punishable by death sentence and confiscation of ships and goods." 98

Corcia and his friends answered Ambrogini, putting forward other arguments. They appealed to his sense of Christian charity. They threatened to bring the Corsican ship captain before the Holy Office of the Roman Inquisition. They accused him to favor the "law of the infidels" and to attach little importance to the "compassion of a poor Christian." 99 They described Ambrogini as a "person who tries to prevent poor Christians fallen into the hands of the Turks from gaining their

\footnotetext{
Page 21 of 36
} 


\section{The Economy of Ransoming in the Early Modern Mediterranean}

freedom."100 Such statement suggests that at the time, commercial interests and religious solidarity were perceived to be in conflict with one another when the latter aimed to favor captives' liberation regardless of the costs that it involved. In the end, the court of Livorno dismissed the case; ${ }^{101}$ a few months later, we find captain Ambrogini trading with Tunis, and not anymore with Algiers. ${ }^{102}$

The maritime or commercial courts of other states did not necessarily agree with the sentence issued by the governor of Livorno in 1624, Don Pietro Medici, who was also a knight of Malta. For instance, at the end of the seventeenth century, in France, a trial against a captain shows how strong the will to respect regular procedures in the ransoming of captives was. A ship captain from Capbreton arrived in Algiers in 1699 and left the North African port city with two escaped Christian captives. Once in Marseilles, the ship captain was arrested, questioned, and fined for 1,500 livres. The two captives were sent back to Algiers to be ransomed according to the rules. As they were from Genoa, one asked the Genoese Republic to pay the customary sum of money for their ransom. ${ }^{103}$

In a context of religious and military conflict between the Muslim and the Christian regions of the Mediterranean, European commerce with the Maghreb required expedients: captives were certainly pitied, but they also served to justify mercantile exchanges and cooperation with the "infidels." The official function of (p.130) corsairing was to damage the economic activities of the enemy. But in practice, corsairing also contributed to intensify exchanges between Christian, Muslim, and Jewish merchants in the western Mediterranean. The circulation of merchant letters and a variety of contracts discussed and signed before notaries, qadi, chancellors, and religious authorities did not create a hybrid law common to all parties involved. Rather, we find evidence of a widespread knowledge of different local rules and customs and the existence of practices and formal standards that could be transferred, applied, and adapted from one religious and geopolitical context to the other. Legal procedures remained different, but local brokers provided translations, not only into other languages but also into other normative frameworks. 


\section{The Economy of Ransoming in the Early Modern Mediterranean}

The centrality of customary knowledge and legal procedures to the organization of cross-cultural trade shows the extent to which the secular and economic actors in particular tried, in the early modern period, to suspend the religious conflict on which the very business of ransoming depended. At the same time, the latent religious conflict always rose to the surface whenever warriors and merchants took new captives by force.

Notes:

(1) About high prices in the economy of ransoming, see Jean Mathiex, "Trafic et prix de l'homme en Méditerranée aux XVIIe et XVIIIe siècles," Annales: Économie, Sociétés, Civilisations, 9 (1954): 157-164; Robert C. Davis, "Slave Redemption in Venice 1595-1797," in Venice Reconsidered: The History and Civilization of an Italian City-State, 12971797, ed. John J. Martin and Denis Romano (Baltimore: Johns Hopkins University Press, 2002), 454-487, 468.

(2) Pierre Ducrey, Le traitement des prisonniers de guerre dans la Grèce antique des origines à la conquête romaine (Paris: E. de Boccard, 1968; rev. ed., Athens: École française d'Athènes, 1999); Anne Bielman, Retour à la liberté: Libération et sauvetage des prisonniers en Grèce ancienne (Athens and Lausanne: École française d'Athènes and Université de Lausanne, 1994); Francisco Vidal Castro, "Le rachat de captifs en al-Andalus (VIIIe-XVe s.): Théorie et pratique du droit et des institutions islamiques," Hypothèses, 1 (2006): 313-327; James W. Brodman, "Municipal Ransoming Law on the Medieval Spanish Frontier," Speculum, 60.2 (1985): 318-330; Kathryn A. Miller, Guardians of Islam: Religious Authority and Muslim Communities of Late Medieval Spain (New York: Columbia University Press, 2008), chap. 7; Youval Rotman, Byzantine Slavery and the Mediterranean World (Cambridge, MA: Harvard University Press, 2009); Adam J. Kosto, Hostages in the Middle Ages (Oxford: Oxford University Press, 2012).

(3) Richard White, The Middle Ground: Indians, Empires, and Republics in the Great Lakes Region, 1650-1815 (Cambridge: Cambridge University Press, 1991); Géza Dávid and Pál Fodor, eds., Ransom Slavery along the Ottoman Borders (Early 


\section{The Economy of Ransoming in the Early Modern Mediterranean}

Fifteenth-Early Eighteenth Centuries) (Leiden and Boston: Brill, 2007).

(4) Alberto Maffi, "Le butin humain dans le monde ancien: Normes et pratiques de la guerre et de la rançon," Hypothèses, 1 (2006): 307-312.

(5) Martha A. Works, "Creating Trading Places on the New Mexican Frontier," Geographical Review, 82.3 (1992): 268281. However, the Portuguese agreed to manumit (alforriar) most of the Tupinambi for services rendered either for specific periods $(5,10$, or 15 years) or until the death of the buyer. After manumission, many of the Indian former slaves were unable to return to their tribe and family clans. See Pedro Puntoni, A Guerra dos Barbáros: Povos indígenas e a colonização do sertão Nordeste do Brasil, 1650-1720 (São Paulo: Editora Hucitec, 2002).

(6) Locke, Two Treatises of Government, II, § 24, in John Locke, Two Treatises of Government [1690]: A Critical Edition with an Introduction and Apparatus Criticus by Peter Laslett, 2nd ed. (Cambridge: Cambridge University Press, 1967), 302.

(7) Maurice H. Keen, The Laws of War in the Late Middle Ages (London: Routledge and K. Paul, 1965), 137-155; Fritz Redlich, De Praeda Militari: Looting and Booty 1500-1815 (Wiesbaden: F. Steiner, 1956); Idem, The German Military Enterpriser and His Work Force: A Study in European Economic and Social History, 2 vols., 2nd ed. (Wiesbaden: F. Steiner, 1964-1965).

(8) Daniel Hohrath, "'In Cartellen wird der Werth eines Gefangenen bestimmet': Kriegsgefangenschaft als Teil der Kriegspraxis des Ancien Régime," in In der Hand des Feindes: Kriegsgefangenschaft von der Antike bis zum Zweiten Weltkrieg, ed. Rüdiger Overmans (Cologne: Publishing House, 1999), 141-170.

(9) Philippe Contamine, "Un contrôle étatique croissant: Les usages de la guerre du XIVe au XVIIIe siècle: rançons et butins," in Guerre et concurrence entre les Etats européens du XIVe au XVIIIe siècle, ed. Philippe Contamine (Paris: Presses

Page 24 of 36

PRINTED FROM OXFORD SCHOLARSHIP ONLINE (www.oxfordscholarship.com). (c) Copyright Oxford University Press, 2015. All Rights Reserved. Under the terms of the licence agreement, an individual user may print out a PDF of a single chapter of a monograph in OSO for personal use (for details see http://www.oxfordscholarship.com/page/privacy-policy). Subscriber: Ecole Normale Superieure; date: 28 October 2016 


\section{The Economy of Ransoming in the Early Modern Mediterranean}

universitaires de France, 1998), 199-236; Jean-François

Chanet and Christian Windler, eds., Les ressources des faibles:

Neutralités, sauvegardes, accommodements en temps de guerre (XVIe-XVIIIe siècles) (Rennes: Presses Universitaires de Rennes, 2009).

(10) Fernand Braudel, The Mediterranean and the Mediterranean World in the Age of Philip II, 2 vols. (Berkeley and Los Angeles: University of California Press, 1995), 2: 865891. See also Michel Fontenay, "Course et piraterie méditerranéennes de la fin du Moyen Age au début du XIXe siècle," Revue d'Histoire Maritime, 6 (2006): 173-228, and Lemnouar Merouche, Recherches sur l'Algérie ottomane II: La course, mythes et réalité (Paris: Bouchène, 2007).

(11) Francesca Trivellato, The Familiarity of Strangers: The Sephardic Diaspora, Livorno, and Cross-Cultural Trade in the Early Modern Period (New Haven, CT: Yale University Press, 2009), 1-2.

(12) Christian Windler, "Diplomatie et interculturalité: Les consuls français à Tunis, 1700-1840," Revue d'Histoire Moderne et Contemporaine, 50.4 (2003): 63-91, 63.

(13) Fredrik Barth, "Introduction," in Ethnic Groups and Boundaries: The Social Organization of Culture Difference, ed. Fredrik Barth (Bergen/Oslo and London: Universitetsforlaget and Allen \& Unwin, 1969), 9-38.

(14) Janice E. Thompson, Mercenaries, Pirates and Sovereigns: State-Building and Extraterritorial Violence in Early Modern Europe (Princeton, NJ: Princeton University Press, 1994). Frederic C. Lane, "Economic Consequences of Organized Violence," Journal of Economic History, 18 (1958): 401-417; idem, Profits from Power: Readings in Protection Rent and Violence-Controlling Enterprises (Albany: State University of New York Press, 1979); Jan Glete, War and the State in Early Modern Europe: Spain, the Dutch Republic and Sweden as Fiscal-Military States, 1500-1660 (London: Routledge, 2002). See also Lauren Benton, A Search for Sovereignty: Law and Geography in European Empires, 1400-1900 (Cambridge: 


\section{The Economy of Ransoming in the Early Modern Mediterranean}

Cambridge University Press, 2010), chap. 3. It seems misleading to refer to the Knights of St. John at Malta as pirates, as in Molly Greene, Catholic Pirates and Greek Merchants: A Maritime History of the Mediterranean (Princeton, NJ: Princeton University Press, 2010). Michel Fontenay has proposed the term "corso," which we find in primary sources, to delineate a specific Mediterranean form of extraterritorial violence based on religious hostility, but not all scholars accept this use. See Michel Fontenay, $\mathrm{La}$ Méditerranée entre la Croix et le Croissant: Navigation, commerce, course et piraterie (XVIe-XIXe siècle) (Paris: Éditions Classiques Garnier, 2010).

(15) Daniel Heller-Roazen, The Enemy of All: Piracy and the Law of Nations (New York: Zone Books, 2009).

(16) For the use of the term "piracy" in various contexts in order to question the legitimacy of those involved in such activities, see Benton, A Search for Sovereignty, 112.

(17) Alessandro Stella, Histoires d'esclaves dans la Péninsule Ibérique (Paris: Éditions de l'École des hautes études en sciences sociales, 2000); Alexis Bernard, "Le logiche del profitto: Schiavi e società a Siviglia nel Seicento," Quaderni Storici, 107.2 (2001): 379-389; Maria Teresa Ferrer I Mallol and Josefina Mutgé i Vives, ed., De l'Esclavitud a la Llibertat: Esclaus i lliberts a l'edat mitjana (Barcelona: CSIC, 2000); Antonio Dominguez Ortiz, "La esclavitud en Castilla durante la Edad Moderna," Estudios de Historia Social de España, 2 (1952): 369-428; Moulay Belhamissi, Les captifs algériens et l'Europe chrétienne (1518-1839) (Algiers: Entreprise nationale du livre, 1988); Claude Meillassoux, "Esclaves, vénacles, captifs et serfs," in Esclavage et dépendances serviles: Histoire comparée, ed. Myriam Cottias, Alessandro Stella, and Bernard Vincent (Paris: L'Harmattan, 2006), 367-373.

(18) Natalie Zemon Davis, Trickster Travels: A SixteenthCentury Muslim between Worlds (New York: Hill and Wang, 2006). 


\section{The Economy of Ransoming in the Early Modern Mediterranean}

(19) Special issue "La schiavitù nel Mediterraneo," Quaderni Storici, 107.2 (2001); Special issue "L'esclavage en Méditerranée à l'époque moderne," Cahiers de la Méditerranée, 65 (2002); Salvatore Bono, Schiavi musulmani nell'Italia moderna: Galeotti, vu' cumpra', domestici (Naples: Edizioni Scientifiche Italiane, 1999); Henri Bresc, ed., Figures de l'esclave au Moyen Âge et dans le monde moderne (Paris: L'Harmattan, 1996); Steven Epstein, Speaking of Slavery: Color, Ethnicity, and Human Bondage in Italy (Ithaca, NY: Cornell University Press, 2001); António de Almeida Mendes "Les réseaux de la traite ibérique dans l'Atlantique nord (1440-1640)," Annales: Histoire, Sciences Sociales, 63.4 (2008): 739-768; Maria Manuel Ferraz Torrão, Tráfico de Escravos entre a Costa da Guiné e a América Espanhola: Articulação dos Impérios Ultramarinos Ibéricos num Espaço Atlântico (1466-1595), Ph.D. thesis, IICT/University of the Açores, 2000, 2 vols.

(20) Archives Nationales Paris (hereafter ANP), A.E. B1, 698, f. 79 (Livorno, December 3, 1683). See also Mathiex, "Trafic et prix de l'homme," 160.

(21) Lemnouar Merouche, Recherches sur l'Algérie ottomane I: Monnaies, prix et revenus 1520-1830 (Paris: Bouchène, 2002), 211.

(22) See also Maura Fortunati, "Captivi, riscatti ed assicurazione alla vigilia dei Codici," in Corsari e riscatto dei captivi: Garanzia notarile tra le due sponde del Mediterraneo, ed. Vito Piergiovanni (Milan: Giuffrè, 2010), 113-134.

(23) Michel Fontenay, "Routes et modalités du commerce des esclaves dans la Méditerranée des temps modernes (XVIe, XVIIe et XVIIIe siècle)," Revue historique, 640.4 (2006): 813830; idem, "Le Maghreb barbaresque et l'esclavage méditerranéen aux XVIème-XVIIème siècles," Les Cahiers de Tunisie, 43 (1991): 7-43; idem, "Esclaves et/ou captifs: préciser les concepts," in Le commerce des captifs: Les intermédiaires dans l'échange et le rachat des prisonniers en Méditerranée, XVe-XVIIIe siècles, ed. Wolfgang Kaiser (Rome: École française de Rome, 2008), 15-24.

Page 27 of 36 


\section{The Economy of Ransoming in the Early Modern Mediterranean}

(24) Sondierungsgröße, in the words of Niklas Luhmann, Die Wirtschaft der Gesellschaft (Frankfurt am Main: Suhrkamp, 1994), 111.

(25) This erroneous parallelism is argued vigorously by Robert C. Davis, Christian Slaves, Muslim Masters: White Slavery in the Mediterranean, the Barbary Coast, and Italy, 1500-1800 (Houndmills: Palgrave Macmillan, 2003). In the Iberian Peninsula, the expression "white slaves" or "white captives" referred to North African slaves and captives. In Italy, by contrast, "white slaves" were those who came from the Black Sea.

(26) Anne Brogini, Malte, frontière de Chrétienté (1530-1670) (Rome: École française de Rome, 2006), 308-309.

(27) Miguel de Cervantes, Don Quijote de la Mancha, ed. Francisco Rico (Barcelona: Galaxia Gutenberg/Círculo de Lectores, 2004), 507 [Part 1, chap. 40]. Diego de Haëdo, Topografía, e historia general de Argel, repartida en cinco tratados do se verán casos extraños, muertes espantosas y tormentos exquisitos que conviene se entendian en la Cristiandad [...] (Valladolid, 1612).

(28) Dávid and Fodor, eds., Ransom Slavery.

(29) On charity and captive redemption in Muslim countries, see Miller, Guardians of Islam, 151-175; Fatiha Loualich, "In the Regency of Algiers: The Human Side of the Algerine Corso," in Trade and Cultural Exchange in the Early Modern Mediterranean: Braudel's Maritime Legacy, ed. Maria Fusaro, Colin Heywood, and Mohamed-Salah Omri (London: Tauris, 2010), 69-96, 85. In the Dutch context and according to Dutch laws, private companies were forced to pay mariners' salaries for as long as the sailors or employees were held prisoners in North Africa. For the companies, it was simply cheaper to ransom entire crews back (even the poor and the humble) than to keep paying their salaries until their death was known. We thank Cátia Antunes for this information. See also Klaas Heeringa, Bronnen tot de Geschiedenis van den Levantschen Handel (1661-1726) (The Hague: Martinus Nijhoff, 1917), 508-510. 


\section{The Economy of Ransoming in the Early Modern Mediterranean}

(30) Such a case in early modern Trapani is described in Carlo Carosi, "Redimere captivos: Appunti sugli atti notarili di riscatto (sec. XVI)," in Corsari e riscatto dei captivi, 47-74, 6263.

(31) Archivio Segreto Vaticano (hereinafter ASV), Arciconfraternita del Gonfalone (hereafter Arciconf. Gonfalone) 1157, fols. 24 and 71. Cf. fn. 40.

(32) Francisco Andújar Castillo, "Los rescates de cautivos en las dos orillas del Mediterráneo y en el mar (Alafías) en el siglo XVI, in Le commerce des captifs, 135-164. Al'áfya (AraboSpanish) or 'âfiyya (classical Arabic) signifies grace, pardon; in Spanish, the expression "pedir alafia" means to plead pardon ("gracia, perdón, misericordia”).

(33) Beatrice Pasciuta, "'Mori, Turchi et altri infidili': Corsari e guerra da corsa in Sicilia fra norme e dottrina," in Corsari $e$ riscatto dei captivi, 151-178; Miriam Hoexter, Endowments, Rulers and Community: Waqf al-Haramayn in Ottoman Algiers (Leiden: Brill, 1998); Loualich, "In the Regency of Algiers," 78-83; Magnus Ressel, "Conflicts between Early modern European States about Rescuing their own subjetcs from Barbary Captivity," Scandinavian Journal of History, 36.1 (2011): 1-22; and the articles of Magnus Ressel, Joachim Östlund, Eric Gøbel, and Leos Müller in Historical Social Research, 35.4 (2010), special issue on "Human Security."

(34) Archives départementales des Bouches du Rhône (hereinafter ADBdR), 9 B 173, "Caier de compte et sentence arbitralle. .." (Marseilles, September 6, 1651).

(35) Fontenay, “Esclaves et/ou captifs," 18.

(36) ANP, A.E. B1, 129, f. 161r-166r (Algiers, April 11, 1757).

(37) For several examples, see Wolfgang Kaiser, "Négocier la liberté: Missions diplomatiques françaises pour l'échange et le rachat des captifs avec le Maghreb au XVIIe siècle," in $L a$ Mobilité des personnes en Méditerranée: Procédures de contrôle et documents d'identification, ed. Claudia Moatti (Rome: École française de Rome, 2004), 501-528. 


\section{The Economy of Ransoming in the Early Modern Mediterranean}

(38) See Wolfgang Kaiser, "Suspendre le conflit: Pratiques de neutralisation entre Chrétiens et Musulmans en Méditerranée (XVIe-XVIIe siècles)," in Les ressources des faibles, 277-290.

(39) ASV, Arciconfr. Gonfalone, 7, fols. 104r-105r (February $26,1585)$.

(40) ASV, Arciconfr. Gonfalone, 1157, fol. 10r (January 10, 1748).

(41) ASV, Arciconfr. Gonfalone, 7, fol. 167v (April 5, 1587):

"Con questa gente non si trova pietà dove ne $[\mathrm{h}]$ a l'interesse dil denaro" (with this people, there is no pity when it is possible to earn money).

(42) On him, see Merouche, Recherches sur l'Algerie II, 191192, 209-210.

(43) ASV, Arciconf. Gonfalone, 1145, nos. 202, 474, 596, 598, 599, 620, 621, 624, 627, 634, 689, 707, 708, 709, 711, 723, 740, 788, 913; ASV, Arciconf. Gonfalone, 8, fols. 49r-52r, $155 \mathrm{r}-156 \mathrm{r}$.

(44) ASV, Arciconfr. Gonfalone, 7, fol. 240r.

(45) Bartolomé Clavero, Antidora: Antropología católica de la economía moderna (Milan: Giuffrè, 1991). For a discussion of the redemption of Mami's slaves, see Wolfgang Kaiser, "Una missione impossibile? Riscatto e comunicazione nel Mediterraneo Occidentale (secoli XVI-XVII)," Quaderni Storici, 124.1 (2007): 19-41.

(46) On the career in various religious orders and in Philip II's army of those Muslim hostages in the Iberian peninsula who converted to Christianity, see Beatriz Alonso Acero, Sultanes de Berbería en tierras de la cristiandad: Exilio musulmán, conversión y asimilación en la Monarquía hispánica (siglos XVI y XVII) (Barcelona: Bellaterra, 2006). On Marseilles and Tunis in 1616, see Archives de la Chambre de Commerce et d'Industrie de Marseille (hereafter ACCIM), G 43, J 1887. On the peace treaties signed between France and the North African states, see Edgard Rouard de Card, Traités de la 


\section{The Economy of Ransoming in the Early Modern Mediterranean}

France avec les pays de l'Afrique du Nord: Algérie, Tunisie, Tripolitaine, Maroc (Paris: A. Pédone, 1906), 14.

(47) Diego Gambetta, Codes of the Underworld: How Criminals Communicate (Princeton, NJ: Princeton University Press, 2009), 54-77. On the use of human pawns in the African slave trade, see Paul E. Lovejoy and David Richardson, "Trust, Pawnship, and Atlantic History: The Institutional Foundations of the Old Calabar Slave Trade," American Historical Review, 104.2 (1999): 333-355.

(48) Copies of the letter and the answer of the viceroy are in Archivo General de Simancas, Estado, leg. 1158, docs. 186 and 187; Biblioteca Apostolica Vatican, Urb. Lat. 1062 fol. 565r-566r (among the collection of avvisi of the duke of Urbino); Biblioteca Nazionale Centrale, Florence, Fondo Nazionale II.IV.310, fol. 185r-186v.

(49) Niklas Luhmann, Vertrauen: Ein Mechanismus der Reduktion sozialer Komplexität (Stuttgart: F. Enke, 1968); English trans. Trust and Power: Two Works by Niklas Luhmann (Chichester: J. Wiley, 1979).

(50) Erving Goffman, Strategic Interaction (Philadelphia: University of Pennsylvania Press, 1969), 105.

(51) Eloy Martín Corrales, Comercio de Cataluña con el Mediterráneo musulmán (siglos XVI-XVIII): El comercio con los "enemigos de la fe" (Barcelona: Bellaterra, 2001), 93. See also Chapter 3 by Giuseppe Marcocci in this volume.

(52) Alberto Anaya Hernández, "Simón Romero, pescador gran canario y gran almirante de la armada argelina," Anuario de Estudios Atlánticos, 49 (2003): 1-21.

(53) ADBdR, 9 B 171 (chancellery of the French Consulate of Algiers, 1579-1582). For the records of the French consular chancellery in Tunis, see Pierre Grandchamp, La France en Tunisie...(1582-1705), 10 vols. (Tunis: Tournier, 1921-1933). For Sicily see Carosi, "Redimere captivos," 56-60.

(54) Kaiser, "Una missione impossibile?" 


\section{The Economy of Ransoming in the Early Modern Mediterranean}

(55) ASV, Arciconfr. Gonfalone, 1157 fol. 11v (February 1748).

(56) ASV, Arciconfr. Gonfalone, 1157, fol. 11r (April 1748), quotation from fol. 10v (February 1748).

(57) ASV, Arcivonfr. Gonfalone, 7, fols. 191r-192v (September 1587), 223r-224r (April 1588).

(58) Kaiser, “Una missione impossibile?”

(59) Wolfgang Kaiser, "La excepción permanente: Actores, visibilidad y asimetrías en los intercambios comerciales entre los paises europeos y el Magreb (siglos XVI-XVII)," in Circulación de personas e intercambios comerciales en el Mediterraneo y en el Atlantico, siglos XVI, XVII, XVIII, ed. José Antonio Martínez Torres (Madrid: CSIC, 2008), 148-163; Giuliana Boccadamo, "Mercanti e schiavi fra Regno di Napoli, Barberia e Levante (secc. XVII-XVIII)," in Rapporti diplomatici e scambi commerciali nel Mediterraneo, ed. Mirella Mafrici (Soveria Mannelli: Rubbettino, 2004), 237-273.

(60) ASV, Arciconfr. Gonfalone, 7, fols. 96r-97r (10 January 1585).

(61) Kaiser, "Una missione impossibile?”

(62) Ciro Manca, "Problemi aperti sul commercio e sul riscatto degli schiavi cristiani nel Mediterraneo dopo Lepanto," Africa, 29 (1974): 549-572; idem, Il modello di sviluppo economico delle città marittime barbaresche dopo Lepanto (Naples: Giannini, 1982).

(63) Luco Lo Basso, “Il prezzo della libertà: L'analisi dei libri contabili del Magistrato per il riscatto degli schiavi della repubblica di Genova all'inizio del XVIII secolo," in Le commerce des captifs, 267-282.

(64) Rosita D’Amora, "Il Pio Monte della Misericordia di Napoli e l'Opera della Redenzione dei Cattivi nella prima metà del XVII secolo," in Le commerce des captifs, 231-247.

(65) Both manuscript and printed albarani can be found in Archivio di Stato di Napoli, Santa Casa della Redentione, bb. 14 and 16, passim. 


\section{The Economy of Ransoming in the Early Modern Mediterranean}

(66) Carosi, "Redimere captivos," 56, 60-62.

(67) Sadok Boubaker, "Réseaux et techniques de rachat des captifs de la course à Tunis au XVIIe siècle," in Le commerce des captifs, 25-46.

(68) Hoexter, Endowments, Rulers and Community, 158.

(69) Loualich, "In the Regency of Algiers," 85.

(70) Miller, Guardians of Islam, chap. 7.

(71) Giuseppe Laras, "La Compagnia per il riscatto degli schiavi di Livorno," Rassegna mensile di Israel, 38 (1972): 86130; Renzo Toaff, “La 'Cassa per il Riscatto degli Schiavi’ del Granduca nella Livorno del Seicento," Studi Livornesi, 1 (1986): 43-64; Eliezer Bashan, "La cause des juifs: Le rachat des captifs dans la société juive méditerranéenne du XIV ${ }^{\mathrm{e}} \mathrm{au}$ $\mathrm{XIX}^{\mathrm{e}}$ siècle," in La société juive à travers l'histoire, ed. Shmuel Trigano, 4 vols. (Paris: Fayard, 1993), 4: 463-472; Magnus Ressel, "The North European Way of Ransoming: Explorations into an Unknown Dimension of the Early Modern Welfare State," Historical Social Research, 35.4 (2010): 125-147; see idem, Zwischen Sklavenkassen und Türkenpässen: Nordeuropa und die Barbaresken in der Frühen Neuzeit (Berlin: de Gruyter, 2012).

(72) Calogero Piazza, Schiavitù e guerra dei Barbareschi: Orientamenti toscani di politica transmarina (1747-1768) (Milan: Giuffrè, 1983), 32-35; Paolo Castignoli, “La Cassa granducale del riscatto a Livorno nel Settecento: Prime note," Nuovi studi livornesi, 8 (2000): 149-154.

(73) Sadok Boubaker, "Négoce et enrichissement individuel à Tunis du XVIIe siècle au début du XIXe siècle," Revue d'histoire moderne et contemporaine, 50.4 (2003): 29-62 ; Mathias Rohe, Das islamische Recht: Geschichte und Gegenwart, 2nd ed. (Munich: Beck, 2009), 107.

(74) Hassan I. Khalilieh, Admiralty and Maritime Laws in the Mediterranean Sea (ca. 800-1050): The Kitāb Akriyat al-Sufun vis-à-vis the Nomos Rhodion Nautikos (Leiden: Brill, 2006). 


\section{The Economy of Ransoming in the Early Modern Mediterranean}

(75) Hassan I. Khalilieh, Islamic Maritime Law: An

Introduction (Leiden: Brill, 1998).

(76) ADBdR, 13 B 14, fols. 169r-170v (July 6, 1578).

(77) Grandchamp, La France en Tunisie, 4: 7, 17, 20.

(78) Daniel Goffman, Britons in the Ottoman Empire, 1642-

1660 (Seattle: University of Washington Press, 1998), 142, see also 24, 42-67.

(79) Archivio di Stato di Livorno (hereafter ASL), Capitano poi Governatore ed Auditore (hereafter GA), Atti Civili, 75, cases $218,228,252$.

(80) Maria Pia Pedani, "Consoli veneziani nei porti del Mediterraneo in età moderna," in Mediterraneo in Armi (secc. $X V$-XVIII), ed. Rossella Cancila, 2 vols. (Palermo: Associazione Mediterranea, 2007), 1: 175-205, 178.

(81) Pedani, "Consoli veneziani," 181; Ivana Burdelez, "Jewish Consuls in the Service of the Republic of Dubrovnik," in Diplomacy of the Republic of Dubrovnik, ed. Svjetlan Berković (Zagreb: Ministery of Foreign Affairs of the Republic of Croatia, Diplomatic Academy, 1998), 337-342.

(82) ASL, GA, Atti Civili, 73, case 207; Archivio di Stato di Pisa (hereafter ASP), Consoli del Mare, Atti Civili, 128, case 29.

(83) James Muldoon, Popes, Lawyers, and Infidels: The Church and the Non-Christian World, 1250-1550 (Philadelphia:

University of Pennsylvania press, 1979), 34 and passim. See also Chapter 3 by Giuseppe Marcocci in this volume.

(84) Géraud Poumarède, Pour en finir avec la Croisade: Mythes et réalités de la lutte contre les Turcs aux XVIe et XVIIe siècles (Paris: Presses universitaires de France, 2009), 315. See also Natividad Planas, "La frontière franchissable: Normes et pratiques dans les échanges entre le royaume de Majorque et les terres d'Islam au XVIIe siècle," Revue d'histoire moderne et contemporaine, 48.2-3 (2001): 123-147.

(85) Poumarède, Pour en finir avec la Croisade, 318.

Page 34 of 36

PRINTED FROM OXFORD SCHOLARSHIP ONLINE (www.oxfordscholarship.com). (c) Copyright Oxford University Press, 2015. All Rights Reserved. Under the terms of the licence agreement, an individual user may print out a PDF of a single chapter of a monograph in OSO for personal use (for details see http://www.oxfordscholarship.com/page/privacy-policy). Subscriber: Ecole Normale Superieure; date: 28 October 2016 


\section{The Economy of Ransoming in the Early Modern Mediterranean}

(86) Leor Halevi, "Christian Impurity versus Economic Necessity: A Fifteenth-Century Fatwa on European Paper," Speculum, 83 (2008): 917-945, 943.

(87) Halevi, "Christian Impurity," 939-940.

(88) Wolfgang Kaiser, “Asymétries méditerranéennes: Présence et circulation de marchands entre Alger, Tunis et Marseilles," in Musulmans en Europe occidentale entre Moyen âge et l'époque moderne, ed. Jocelyne Dakhlia and Bernard Vincent (Paris: Albin Michel, 2011), 417-442. For the eighteenth century, see Jean Mathiex, "Sur la marine marchande barbaresque au XVIIIe siècle," Annales: Économies, Sociétés et Civilisations, 13.1 (1958): 87-93.

(89) Rafael Benitez, "La tramitación del pago de rescates a través del reino de Valencia: El último plazo del rescate de Cervantes," in Le commerce des captifs, 193-217, 217.

(90) ASP, Consoli del mare, Atti Civili, 125, case 30 (hereafter 125/30), March 8, 1625, chapters of cross-examination: "né vi era notitia che havesse mutato costumi, né meno che havesse fatto attioni per le quali si potesse credere che fusse diventato huomo da bene et così" (there was no indication that he had changed his manners, nor that he had acted in ways that would have made him into a respectable person).

(91) ASP, Consoli del mare, Atti Civili, 125/30, February 19, 1625.

(92) ASP, Consoli del mare, Atti Civili, 125/30, March 8, 1625.

(93) ASP, Consoli del mare, Atti Civili, 125/30, March 8, 1625, petition by Camillo Paccalli, Giovanni Stefano Boccalandro, Origene Mercante, and Gualtiere Cesare; ASP, Consoli del mare, Atti Civili, 125/30, April 14, 1625, appearance in court of Joseph Franco; ASP, Consoli del mare, Suppliche, 974, no. 100.

(94) ASP, Consoli del mare, Atti Civili, 125/30, April 14, 1625, appearance in court of Joseph Franco.

Page 35 of 36

PRINTED FROM OXFORD SCHOLARSHIP ONLINE (www.oxfordscholarship.com). (c) Copyright Oxford University Press, 2015. All Rights Reserved. Under the terms of the licence agreement, an individual user may print out a PDF of a single chapter of a monograph in OSO for personal use (for details see http://www.oxfordscholarship.com/page/privacy-policy). Subscriber: Ecole Normale Superieure; date: 28 October 2016 


\section{The Economy of Ransoming in the Early Modern Mediterranean}

(95) ASP, Consoli del mare, Suppliche, 974, no. 100, May 11, 1625.

(96) The ship Il Sole and its owner obtained a license to sail to Algiers and Tunis on February 19, 1621. ASP, Consoli del mare, Atti Civili, 125/30, copy of the license for the ship named Il Sole.

(97) The following account is based on the trial records found in ASL, GA, 73, case 4 (hereafter 73/4), fols. 409-441.

(98) ASL, GA, 73/4, fol. 437.

(99) ASL, GA, 73/4, fol. 409.

(100) ASL, GA, 73/4, fol. 409v.

(101) ASL, GA, 73/4, fol. 415.

(102) ASL, GA, 73, case 262.

(103) ACCIM, G 47.

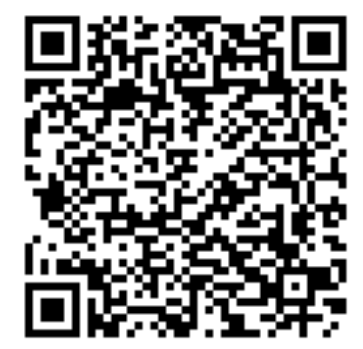

Access brought to you by: Ecole Normale Superieure 